Cochrane Database of Systematic Reviews

\title{
Beta radiation for glaucoma surgery (Review)
}

Kirwan JF, Rennie C, Evans JR

Kirwan JF, Rennie C, Evans JR.

Beta radiation for glaucoma surgery.

Cochrane Database of Systematic Reviews 2012, Issue 6. Art. No.: CD003433.

DOI: 10.1002/14651858.CD003433.pub3.

www.cochranelibrary.com 
TABLE OF CONTENTS

HEADER

ABSTRACT

PLAIN LANGUAGE SUMMARY

SUMMARY OF FINDINGS

BACKGROUND

OBJECTIVES

METHODS

RESULTS

Figure 1.

Figure 2.

DISCUSSION

AUTHORS' CONCLUSIONS

ACKNOWLEDGEMENTS

REFERENCES

CHARACTERISTICS OF STUDIES

DATA AND ANALYSES

Analysis 1.1. Comparison 1 Surgical failure, Outcome $1 \mathrm{IOP}>21 \mathrm{mmHg} 12$ months or more after surgery.

Analysis 2.1. Comparison 2 Intraocular pressure (IOP), Outcome 1 Mean IOP 12 months or more after surgery.

Analysis 3.1. Comparison 3 Adverse effects, Outcome 1 Cataract.

Analysis 3.2. Comparison 3 Adverse effects, Outcome 2 Hypotony.

Analysis 3.3. Comparison 3 Adverse effects, Outcome 3 Bleb leak.

ADDITIONAL TABLES

APPENDICES

WHAT'S NEW

HISTORY

CONTRIBUTIONS OF AUTHORS

DECLARATIONS OF INTEREST

SOURCES OF SUPPORT

DIFFERENCES BETWEEN PROTOCOL AND REVIEW

INDEX TERMS 
[Intervention Review]

\section{Beta radiation for glaucoma surgery}

James F Kirwan¹, Christina Rennie², Jennifer R Evans ${ }^{3}$

1Department of Ophthalmology, Queen Alexandra Hospital, Portsmouth, UK. 2Department of Ophthalmology, Southampton Eye Unit, Southampton General Hospital, Southampton, UK. ${ }^{3}$ Cochrane Eyes and Vision Group, ICEH, London School of Hygiene \& Tropical Medicine, London, UK

Contact address: James F Kirwan, Department of Ophthalmology, Queen Alexandra Hospital, Cosham, Portsmouth, Hampshire, PO6 3LY, UK. jfkirwan@mac.com.

Editorial group: Cochrane Eyes and Vision Group.

Publication status and date: New search for studies and content updated (no change to conclusions), published in Issue 6, 2012.

Citation: Kirwan JF, Rennie C, Evans JR. Beta radiation for glaucoma surgery. Cochrane Database of Systematic Reviews 2012 , Issue 6. Art. No.: CD003433. DOI: 10.1002/14651858.CD003433.pub3.

Copyright $\odot 2012$ The Cochrane Collaboration. Published by John Wiley \& Sons, Ltd.

\section{A B S T R A C T}

\section{Background}

The outcome of glaucoma surgery can be affected by the rate at which the surgical wound heals. Beta radiation has been proposed as a rapid and simple treatment to slow down the healing response.

\section{Objectives}

To assess the effectiveness of beta radiation during glaucoma surgery (trabeculectomy).

\section{Search methods}

We searched CENTRAL (which contains the Cochrane Eyes and Vision Group Trials Register) (The Cochrane Library 2012, Issue 3), MEDLINE (January 1950 to March 2012), EMBASE (January 1980 to March 2012), the metaRegister of Controlled Trials (mRCT) (www.controlledtrials.com), ClinicalTrials.gov (www.clinicaltrials.gov) and the WHO International Clinical Trials Registry Platform (ICTRP) (www.who.int/ ictrp/search/en). There were no date or language restrictions in the electronic searches for trials. The electronic databases were last searched on 26 March 2012.

\section{Selection criteria}

We included randomised controlled trials comparing trabeculectomy with beta radiation to trabeculectomy without beta radiation.

\section{Data collection and analysis}

We collected data on surgical failure (intraocular pressure $>21 \mathrm{mmHg}$ ), intraocular pressure and adverse effects of glaucoma surgery. We pooled data using a fixed-effect model.

\section{Main results}

We found four trials that randomised 551 people to trabeculectomy with beta irradiation versus trabeculectomy alone. Two trials were in Caucasian people (126 people), one trial in black African people (320 people) and one trial in Chinese people (105 people). People who had trabeculectomy with beta irradiation had a lower risk of surgical failure compared to people who had trabeculectomy alone (pooled risk ratio (RR) 0.23 ( $95 \% \mathrm{Cl} 0.14$ to 0.40 ). Beta irradiation was associated with an increased risk of cataract ( $\mathrm{RR} 2.89,95 \% \mathrm{Cl} 1.39$ to 6.0$)$.

\section{Authors' conclusions}

Trabeculectomy with beta irradiation has a lower risk of surgical failure compared to trabeculectomy alone. A trial of beta irradiation versus anti-metabolite is warranted. 


\section{PLAIN LANGUAGE SUMMARY}

\section{Beta radiation in glaucoma surgery}

The aim of glaucoma surgery is to lower the pressure in the eye. The outcome of glaucoma surgery can be affected by the rate at which the surgical wound heals. Beta radiation has been proposed as a rapid and simple treatment to slow down the healing response. It is applied during the operation using a radioactive applicator which emits beta rays which have only a very local penetration to a depth of less than one millimetre. The intensity of the emission from the applicator (usually Strontium-90) determines the duration it is applied to the surgical site in order to deliver the required dose of radiation which effectively prevents scar tissue formation.

We found four trials that randomised 551 people to trabeculectomy with beta irradiation versus trabeculectomy alone. People who had trabeculectomy with beta irradiation were less likely to have an eye pressure that was too high one year after surgery compared to people who had trabeculectomy alone. However, people who had beta irradiation had an increased risk of cataract after surgery. 
GRADE Working Group grades of evidence

High quality: Further research is very unlikely to change our confidence in the estimate of effect.

Moderate quality: Further research is likely to have an important impact on our confidence in the estimate of effect and may change the estimate.

Low quality: Further research is very likely to have an important impact on our confidence in the estimate of effect and is likely to change the estimate.

Very low quality: We are very uncertain about the estimate.

1 Based on control events in included studies. Higher risks of surgical failure seen in black African populations.

2 Majority of evidence from larger high quality study in black African people. However, relative risks for smaller studies in Caucasian and Chinese people were of a similar order but imprecise (pooled relative risk 0.15 ( $95 \% \mathrm{Cl} 0.02$ to 1.28 ).

3 Data for Caucasian patients only.

4 Two studies contributed data to this outcome, $n=123$ people. Pooled mean difference was $-0.97(-2.56,0.62)$. i.e. beta radiation compatible with a reduction of approximately $2.5 \mathrm{mmHg}$ intraocular pressure but also with an increased pressure of less than $1 \mathrm{mmHg}$.

5 Barnes 2000 and Kirwan 2006 had similar estimates of the risk of cataract associated with beta irradiation of approximately 3 to 3.5 . In contrast Rehman 2002 had a relative risk reduction of 50\%. However, there were small numbers of events (2 cataracts in each group) in Rehman 2002.

6 The pooled analysis had a total of 9 events in the treatment group and 4 in the control group. 


\section{B A C K G R O U N D}

Beta radiation inhibits wound healing, and has been shown to improve survival of glaucoma filtration surgery in vitro and in vivo (Khaw 1991). Beta radiation causes growth-arrest, primarily due to its effects on P450 (a controller of cell cycling), rather than producing destruction of cells (Constable 1999).

\section{Description of the condition}

The term glaucoma defines a group of conditions in which there is characteristic optic neuropathy associated with progressive visual field loss (loss of peripheral and then central vision). Raised intraocular pressure (IOP) is recognised to be one of the principal risk factors for glaucoma (Buhrmann 2000; Hollows 1966; Leske 1995). Glaucoma is the commonest cause of irreversible blindness worldwide, with at least 70 million people affected and over seven million blind from the condition (Quigley 1996). With an ageing world population, the prevalence is likely to increase considerably in the coming years.

\section{Description of the intervention}

Lowering IOP has long been established as a means of treating glaucoma, despite a lack of good data for its effectiveness in preventing visual field loss (Rossetti 1993; Vass 2007). What information we do have suggests that surgery is currently the most effective means of lowering IOP (Burr 2004; Migdal 1986, Lichter 2001). Trabeculectomy is the most widely used surgical procedure for glaucoma. In the developed world, surgery is used where other modalities (medical or laser therapy or both) are not sufficiently effective. In poorer countries trabeculectomy may be used as a primary treatment for glaucoma.

The aim of the trabeculectomy operation is to create a fistula (channel) between the anterior chamber and the subconjunctival space to allow controlled release of fluid from the eye. A partialthickness scleral flap is fashioned at the limbus, with a sclerostomy created under this flap forming a so-called guarded fistula. Fluid from the anterior chamber drains out of the eye through this fistula to the subconjunctival space forming a conjunctival bleb. Fluid in this bleb is thought to be carried away by vessels within the conjunctiva and also by passing through the conjunctival wall. Final IOP may be determined by the size of the bleb, downstream drainage from the conjunctival vessels and the healing response of the eye. The most common cause for failure of trabeculectomy is subconjunctival fibrosis (Hitchings 1983) resulting in occlusion of the fistula with loss of IOP lowering effect.

In elderly white people with glaucoma who have not had prior eye surgery, the success rate of surgery is considered to be in the region of $80 \%$. However, the success rate is lower in certain groups including black people, people with ocular inflammation or neovascularisation, those who have had previous ocular surgery and children (Ritch 1996). It is also apparent that prior topical medical treatment may prejudice the overall success of surgery (Broadway 1994; Lavin 1990).

Various agents have been used to reduce the excessive healing that leads to failure of trabeculectomy. The most widely used agents are Mitomycin C and 5-Fluorouracil. Mitomycin C was introduced in 1983 although widespread use did not occur until the mid 1990s (Chen 1983). 5-Fluorouracil was introduced in 1984, after positive reports from a randomised controlled trial (RCT), and was used widely until use of Mitomycin C became widespread (FFSG 1996; Heuer 1984; Singh 2000). Systematic reviews of postoperative 5Fluorouracil (Wormald 2001) and of intraoperative Mitomycin C (Wilkins 2005) are already published in The Cochrane Library.

Although both of these antimetabolites have proven effective clinically they are associated with complications. Both Mitomycin $\mathrm{C}$ and 5-Fluorouracil are used in liquid form, delivered by placing microsurgical sponges soaked in the drug directly onto the operative site. Because the antimetabolites are liquids they carry the risk of leakage away from the treatment site. This leakage can lead to extraocular or, more seriously, intraocular toxicity (Franks 1991). Furthermore, the variability of the delivery of the drug between the impregnated sponge and the subconjunctival tissues means that accurate dosimetry has proven difficult. Both treatments have been associated with the development of thin, avascular filtration blebs, and these are in turn associated with an increased risk of sight threatening complications including hypotony (a very soft eye) and endophthalmitis (ocular infection) (Wolner 1991; Yaldo 1993; Zacharia 1993).

One alternative to the use of antimetabolites is beta radiation. Precise control of dose and area of treatment may be easily achieved as it is applied using a Strontium-90 applicator at the completion of surgery. The doses used are typically $750 \mathrm{cGy}$ or 1000 cGy and single application is used without fractionation. Beta radiation was first used for glaucoma surgery in the 1940s (Iliff 1944) and has been used at Moorfields Eye Hospital for many years in the management of paediatric glaucoma. Good results were reported with a non-randomised retrospective study in a cohort of these patients (Miller 1991). Beta radiation may be especially suitable for use in developing countries due to the technical simplicity of application and as no running costs are required.

\section{Why it is important to do this review}

Recently, several workers have described the use of beta radiation with trabeculectomy. The overall effectiveness of this mode of therapy is unknown and a systematic review is needed to assess the effects both in people where a high success rate is expected and in those where a lower success rate would be expected.

\section{O B JECT IVES}

The aims of this review were to assess the effects of beta radiation with trabeculectomy on surgical failure due to postoperative scarring in people with glaucoma. Mean IOP was an additional primary outcome. The review also aimed to gather evidence on whether beta radiation is associated with increased complications after surgery as compared to standard trabeculectomy.

\section{METHODS}

\section{Criteria for considering studies for this review}

\section{Types of studies}

We included randomised controlled trials (RCTs).

\section{Types of participants}

We included trials in which participants were people with glaucoma undergoing trabeculectomy. All glaucoma diagnosis categories were included. We included people undergoing a first surgical procedure without any perceived risk factors for surgical failure and 
people who were considered to have a high risk of surgical failure. We did not include people undergoing simultaneous bilateral surgery.

\section{Types of interventions}

We included trials in which trabeculectomy with beta radiation applied at any dose was compared to trabeculectomy alone, with placebo or with another anti-scarring agent. We excluded trials in which trabeculectomy was combined with cataract extraction.

\section{Types of outcome measures}

\section{Primary outcomes}

The primary outcome measures for this review were:

1. the proportion of failed trabeculectomies at 12 months or more after surgery (defined as repeat surgery or uncontrolled IOP more than $20 \mathrm{mmHg}$ with or without additional topical or systemic medications);

2. mean IOP at 12 months or more. Intraocular pressure is used as a primary outcome measure for many clinical trials in glaucoma. The ideal outcome measure is visual function, most commonly expressed in terms of visual field (with allowance for visual acuity) However, the difficulty in determining visual field progression due to the inherently high noise in this psychophysical measure means that trials using this outcome measure need to be performed with large sample sizes and long follow-up time. For practical reasons, IOP was used as a surrogate measurement; the degree of IOP reduction appears to be related to the rate of visual field progression (Gaasterland 2000).

\section{Secondary outcomes}

Secondary outcome measures included:

3. adverse effects including;

a. visual loss,

b. wound leaks: the presence of a positive Seidel test (visible aqueous flow with the tear film stained with fluorescein),

c. late endophthalmitis - an infection of the globe contents that even with prompt aggressive treatment often results in substantial loss of visual function. 'Late' here implies infection arising from organisms gaining access to the globe through thin walled drainage blebs or frank breaks in the conjunctival epithelium after the immediate postoperative period when infectious agents may have entered the eye during the surgical procedure,

d. hypotony: the IOP is below five millimetres mercury and/or associated with complications such as macular oedema and sight loss or choroidal detachments,

e. cataract: the subsequent development of visually significant cataract.

4. outcomes relating to quality of life or patient's perspective of care;

5. data relevant to economic evaluation.

\section{Search methods for identification of studies}

\section{Electronic searches}

We searched the Cochrane Central Register of Controlled Trials (CENTRAL) 2012, Issue 3, part of The Cochrane
Library. www.thecochranelibrary.com (accessed 26 March 2012), MEDLINE (January 1950 to March 2012), EMBASE (January 1980 to March 2012), the metaRegister of Controlled Trials (mRCT) (www.controlled-trials.com), ClinicalTrials.gov (www.clinicaltrials.gov) and the WHO International Clinical Trials Registry Platform (ICTRP) (www.who.int/ictrp/search/en). There were no language or date restrictions in the search for trials. The electronic databases were last searched on 26 March 2012.

See: Appendices for details of search strategies for CENTRAL (Appendix 1), MEDLINE (Appendix 2), EMBASE (Appendix 3), $m R C T$ (Appendix 4), ClinicalTrials.gov (Appendix 5) and the ICTRP (Appendix 6).

\section{Searching other resources}

We manually searched the Association for Research in Vision and Ophthalmology (ARVO) abstract books from 1990 to 2009 using a keyword index search for relevant studies. Keywords used were: radiation; beta radiation; strontium. All studies with these words in the permuted index were examined to see if they were relevant. We contacted researchers who are active in the field and manufacturers of the emitter for information on further published or unpublished studies.

\section{Data collection and analysis}

\section{Selection of studies}

Two authors independently screened the titles and abstracts obtained by the searches and full copies of definitely or potentially relevant studies were obtained. Where the trial had not been fully reported, or was unreported, we attempted to contact the investigators and endeavour to obtain as much relevant data as possible. Details of the trial were not masked during the assessment.

\section{Data extraction and management}

One review author entered the data into RevMan 5 (Review Manager 2011) and a second review author independently verified the data entry. Any disagreements between review authors were resolved by discussion.

\section{Assessment of risk of bias in included studies}

Relevant details about study design were extracted independently by two authors. Risk of bias was assessed using The Cochrane Collaboration's tool for assessing risk of bias as described in Chapter 8 of the Cochrane Handbook for Systematic Reviews of Interventions (Higgins 2011). We contacted study authors for further information on any item graded as unclear.

\section{Data synthesis}

For description of dichotomous data such as failure rates, a summary odds ratio was calculated. For IOP, the weighted mean difference was reported. As there were three studies or less to be combined, we used a fixed-effect model. If further trials are included in future updates of this review we will use a randomeffects model.

There were not enough published studies to investigate potential publication bias nor to conduct sensitivity analyses as planned in the protocol (excluding poorer quality studies). 


\section{Subgroup analysis and investigation of heterogeneity}

No subgroup analyses were planned in the protocol. The included trials were conducted in different populations (black African, Caucasian and Chinese). There is some evidence that people of African origin have a higher risk of surgical failure (AGIS 2001). In the included trials there was some evidence that the control group risk of failure of surgery was different in different ethnic groups (see Table 1). We therefore did a (posthoc) subgroup analysis by ethnic group.

\section{RES U L T S}

\section{Description of studies}

\section{Results of the search}

The electronic searches identified 1180 titles and abstracts. We screened the title and abstracts and obtained full-text copies of five reports to assess for potential inclusion in the review. Four studies were eligible for inclusion and one study was excluded, see the 'Characteristics of excluded studies' table for further information.

An update search was done in March 2012 which yielded a further 93 references. We screened the search results but found no new studies which met the inclusion criteria.

\section{Included studies}

See Table 1 and 'Characteristics of included studies' for further details. Four trials were found (Barnes 2000; Lai 1994; Rehman
2002; Kirwan 2006). Two trials (Barnes 2000; Rehman 2002) were performed in Caucasian people, with primary open angle glaucoma with an expected high success rate. Lai 1994 was found in abstract form, which had been performed in Chinese people with open angle glaucoma. The success rate in this trial was also expected to be high, although not as high as for Caucasian people. One trial was performed in black African patients (Kirwan 2006). Two trials used a dosage of 750 cGy (Barnes 2000; Rehman 2002) and two trials used a dosage of 1000 cGy (Kirwan 2006; Lai 1994).

A total of 551 people were randomised in these four trials. Followup ranged from 12 months (Rehman 2002) to four years (Kirwan 2006).

\section{Excluded studies}

See Characteristics of excluded studies for details.

\section{Risk of bias in included studies}

See Figure 1 and Figure 2. The trials reported as research papers were of acceptable methodological quality (Barnes 2000; Kirwan 2006; Rehman 2002). In all three trials, sealed envelopes with a randomised number sequence were used for allocation concealment. Examiners determining outcome were unaware of trial allocation. The study published in abstract form has not been subsequently published but we were able to get some information from the trial investigator who reported adequate allocation concealment. Intention-to-treat analysis was not formally reported in any trial. In all trials, only one eye was entered into the trial. 
Figure 1. Methodological quality summary: review authors' judgements about each methodological quality item for each included study.

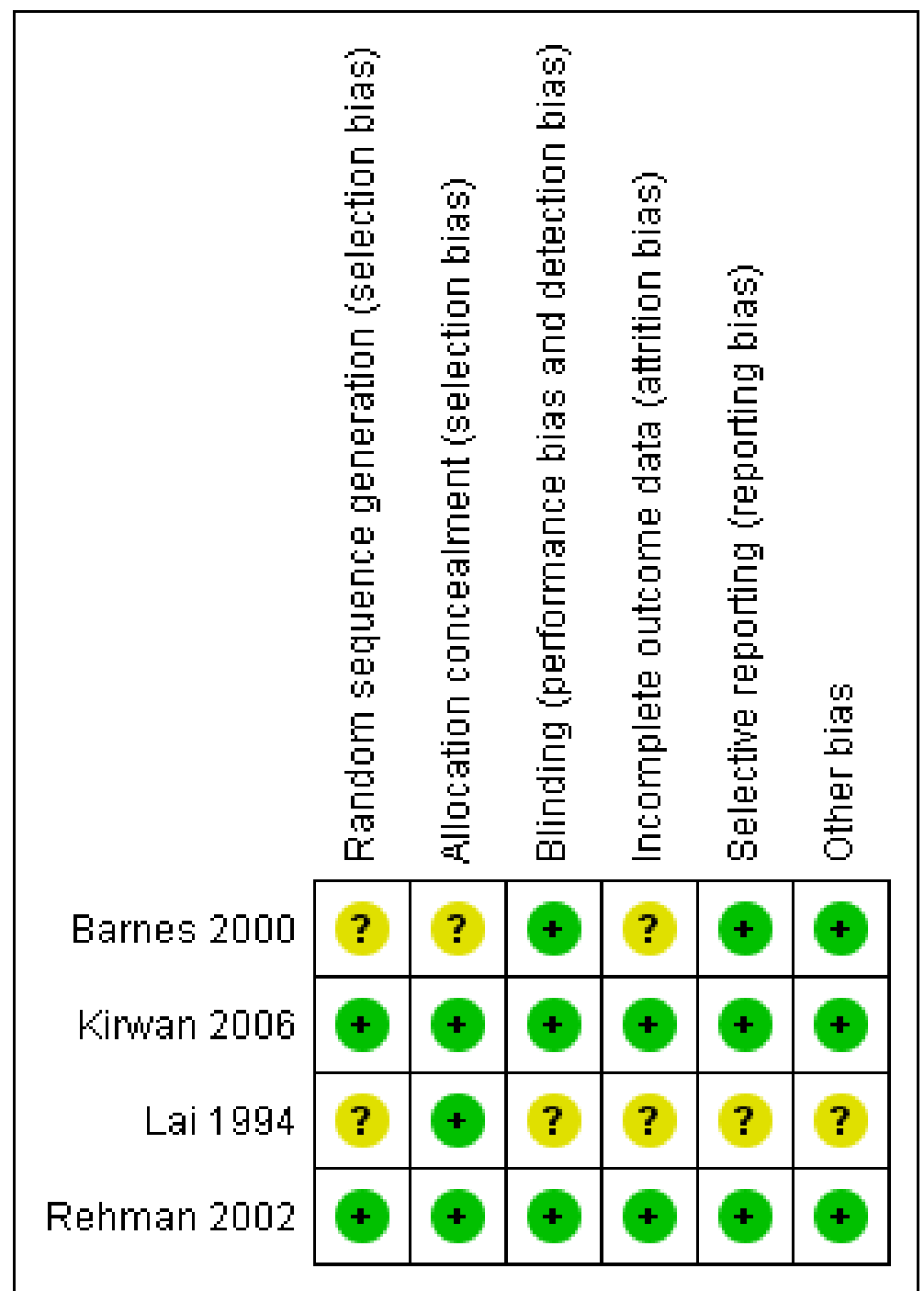


Figure 2. Methodological quality graph: review authors' judgements about each methodological quality item presented as percentages across all included studies.

\section{Random sequence generation (selection bias)}

Allocation concealment (selection bias)

Blinding (performance bias and detection bias)

Incomplete outcome data (attrition bias)

Selective reporting (reporting bias)

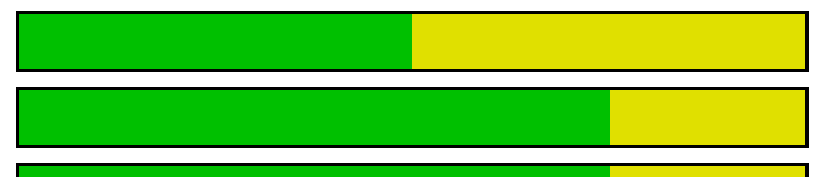

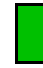

Other bias

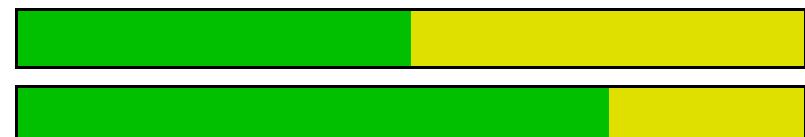

Selective reporting (reporting bias)
Other bias
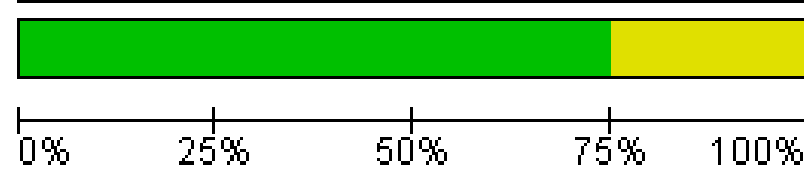

\section{Low risk of bias}

\section{Unclear risk of bias}

High risk of bias

\section{Effects of interventions}

See: Summary of findings for the main comparison

People who had trabeculectomy with beta irradiation had a lower risk of surgical failure one year after surgery compared to people who had trabeculectomy alone (Analysis 1.1 pooled risk ratio 0.23 (95\% confidence interval ( $\mathrm{Cl}) 0.14$ to 0.40$)$ ). The treatment effect appeared to be similar in the different ethnic groups. However the three trials in non African people were smaller and the risk of surgical failure lower in Caucasian people. In the two trials of Caucasian people there were no cases of surgical failure in the treatment group. This analysis, therefore, does not have good power to detect true differences in treatment effect in the different ethnic groups. Only two trials reported mean IOP at the end of the study (Analysis 2.1). People receiving beta irradiation had on average $1 \mathrm{mmHg}$ lower IOP 12 months after surgery. However, this result was not statistically significant and the result is compatible with both lower and higher IOP after surgery (pooled mean difference $-0.9795 \% \mathrm{Cl}-2.56$ to 0.62 ).

The most recent study conducted on a South African population was the largest with the greatest power to detect a difference. In this study relative risk of failure was $0.21(95 \% \mathrm{Cl} 0.11$ to 0.40$)$ at one year (Kirwan 2006).

The two trials reporting results in Caucasians both had very high success rates. The study from New Zealand, Barnes 2000 showed a small trend for people having beta radiation to have a higher success rate, a lower IOP and a larger drop in IOP. None of these results were significant. The study from Leeds, Rehman 2002 had success rates of $95 \%$ and $100 \%$ in each arm of the trial for the most generous definition of success and high success rates, even for more stringent definitions. There was no significant difference in success rates between the two arms of the trial for any outcome measure. Neither study had sufficient power to compare adverse effect rates.The Hong Kong study, Lai 1994 demonstrated a significant difference in success between the two arms of the study. The failure rate was $25 \%$ in the control arm and $9 \%$ in the treatment arm.
Adverse effects were reported in all studies but numbers were low. There was evidence of an increased risk of cataract requiring surgical intervention in the treatment group (Analysis 3.1 pooled risk ratio $2.89(95 \% \mathrm{Cl} 1.39$ to 6.00$))$. Numbers of other complications were too low to comment on (Analysis 3.2; Analysis 3.3), although there was a suggestion that beta radiation augmented trabeculectomy was associated with a small increase in the risk of ocular hypotony (Analysis 3.2).

\section{DISCUSSION}

Several points are worthy of comment in considering the data. In the Barnes 2000 study, four participants had only three months follow-up. We were able to obtain the raw data from the investigators. One of those four participants had failed surgery with an IOP $21 \mathrm{mmHg}$ or more at three months. We have counted this patient as a surgical failure at 12 months as well. For the other three patients who had an IOP less than $21 \mathrm{mmHg}$ at three months we cannot make any assumptions about their status at 12 months. The dose used for both the Rehman 2002 and Barnes 2000 studies was 750 cGy, this is less than the dose used in Lai 1994 and cell culture and in vivo animal data suggests that the difference may be a biologically significant one. In the Lai study, the numbers were reported as percentages only and no further information was obtained from the study author.

From the limited data available, it appears that beta radiation improves success rates in people with an intermediate surgical prognosis and possibly in those with an already good surgical prognosis. This may be at the cost of an increased rate of cataract development.

The degree of improvement in success is similar to that of other antimetabolites but there is no trial data comparing beta radiation with other metabolites such as Mitomycin C or 5-Fluorouracil.

In a developing world setting, with a high surgical volume, beta radiation has advantages in that there are no ongoing costs and it has a long service life (more than 20 years) although capital outlay is significant (approximately $£ 5000$ to purchase a Sr90 emitter in 
the UK). A further issue is that in the UK and many other countries, a government licence is required to use a radioactive device. Obtaining this may necessitate extra training; this and associated bureaucracy may place a barrier on the use of an emitter. In the UK, storage is in a lead lined repository, usually in the medical physics department. However, this may be excessive given the attenuation of Sr90 in air and storage in an area with a significant physical distance from those in the working environment is considered to be adequate in many settings.

\section{AUTHORS' CONCLUSIONS}

\section{Implications for practice}

Beta radiation-augmented trabeculectomy reduces the risk of surgical failure compared to standard trabeculectomy. It may be clinically useful but it is unknown how it compares in both effectiveness and safety to other, more widely used antimetabolites. Data on adverse effects are limited. A specific role for beta radiation is unclear and this depends on there being more evidence available to guide practice.

\section{Implications for research}

There are only four trials of beta radiation for increasing the probability of success in trabeculectomy. Much of the existing evidence for controlling wound healing after trabeculectomy concentrates on liquid antimetabolites. How beta radiation compares to liquid antimetabolites is unknown. Beta radiation may be particularly useful in a developing world setting but this has yet to be evaluated. Outcomes of particular interest are the degree of IOP lowering, success rates in the long term, and adverse effects particularly cataract. Further trials comparing beta radiation with other antimetabolites would be useful in such a setting but may also be of relevance to richer countries.

\section{ACKNOWLEDGEMENTS}

We are grateful to the peer reviewers including David Broadway, Catey Bunce and Suzanne Brodney-Folse for comments on this review and to investigators who shared their data with us. The Cochrane Eyes and Vision Group created and executed the search results. We thank Anupa Shah and Iris Gordon for their help with the review process.

Richard Wormald (Co-ordinating Editor for CEVG) acknowledges financial support for his CEVG research sessions from the Department of Health through the award made by the National Institute for Health Research to Moorfields Eye Hospital NHS Foundation Trust and UCL Institute of Ophthalmology for a Specialist Biomedical Research Centre for Ophthalmology. The views expressed in this publication are those of the authors and not necessarily those of the Department of Health. 


\section{RE F E R E N C E S}

\section{References to studies included in this review}

Barnes $\mathbf{2 0 0 0}$ \{published data only\}

* Barnes RM, Mora JS, Best SJ. Beta radiation as an adjunct to low-risk trabeculectomy. Clinical and Experimental Ophthalmology 2000;28(4):259-62.

\section{Kirwan 2006 \{published data only\}}

* Kirwan JF, Cousens S, Venter L, Cook C, Stulting A, Roux P, et al. Effect of beta radiation on success of glaucoma drainage surgery in South Africa: randomised controlled trial. BMJ 2006;333(7575):942.

\section{Lai 1994 \{published data only\}}

Lai JSM, Ho PCP. Trabeculectomy combined with beta irradiation in uncomplicated primary open angle glaucoma. Investigative Ophthalmology and Visual Science 1994;35:Abstract number 825 .

\section{Rehman 2002 \{published data only\}}

Rehman SU, Amoaku WM, Doran RM, Menage MJ, Morrell AJ. Randomized controlled clinical trial of beta irradiation as an adjunct to trabeculectomy in open-angle glaucoma. Ophthalmology 2002;109(2):302-6.

\section{References to studies excluded from this review}

Tesha 2002 \{published data only\}

Tesha PE, Rehman SU, Amoaku WMK, Doran RML, Menage MJ, Morrell AJ. Investigation into the use of beta irradiation as an adjunct to trabeculectomy in open angle glaucoma. Congress of the Royal College of Ophthalmologists. 2002.

\section{Additional references}

\section{AGIS 2001}

AGIS Investigators. The Advanced Glaucoma Intervention Study (AGIS): 9. Comparison of glaucoma outcomes in black and white patients within treatment groups. American Journal of Ophthalmology 2001;132(3):311-20.

\section{Broadway 1994}

Broadway DC, Grierson I, O'Brien C, Hitchings RA. Adverse effects of topical antiglaucoma medication regimes: Part II. Effect on the outcome of filtration surgery. Archives of Ophthalmology 1994;112:1446-54.

\section{Buhrmann 2000}

Buhrmann RR, Quigley HA, Barron Y, West SK, Oliva MS, Mmbaga BB. Prevalence of glaucoma in a rural East African population. Investigative Ophthalmology and Visual Science 2000;41(1):40-8.

\section{Burr 2004}

Burr J, Azuara-Blanco A, Avenell A. Medical versus surgical interventions for open angle glaucoma. Cochrane Database of Systematic Reviews 2004, Issue 2. [DOI: 10.1002/14651858.CD004399.pub2]

\section{Chen 1983}

Chen CW. Enhanced intraocular pressure controlling effectiveness of trabeculectomy by local application of mitomycin C. Transactions of the Congress of the Asia-Pacific Academy of Ophthalmology 1983:172.

\section{Constable 1999}

Constable $\mathrm{PH}$. The effect of single doses of beta radiation on the wound healing functions of ocular fibroblasts [MD thesis]. Cambridge: University of Cambridge, 1999.

\section{FFSG 1996}

The Fluorouracil Filtering Surgery Study Group. Five-year follow-up of the Fluorouracil Filtering Surgery Study. American Journal of Ophthalmology 1996;121(4):349-66.

\section{Franks 1991}

Franks WA, Hitchings RA. Complications of 5-fluorouracil after trabeculectomy. Eye 1991;5(Pt 4):385-9.

\section{Gaasterland 2000}

Gaasterland DE, Ederer F, Beck A, Costarides A, Leef D, Closek J, et al. The AGIS Investigators. The advanced glaucoma intervention study (AGIS): 7. The relationship between control of intraocular pressure and visual field deterioration. American Journal of Ophthalmology 2000;130(4):429-40.

\section{Glanville 2006}

Glanville JM, Lefebvre C, Miles JN, Camosso-Stefinovic J. How to identify randomized controlled trials in MEDLINE: ten years on. Journal of the Medical Library Association 2006;94(2):130-6.

\section{Heuer 1984}

Heuer DK, Parrish RK 2d, Gressel MG, Hodapp E, Palmberg PF, Anderson DR. 5-fluorouracil and glaucoma filtering surgery. II. A pilot study. Ophthalmology 1984;91(4):384-94.

\section{Higgins 2011}

Higgins JPT, Altman DG, Sterne JAC (editors). Chapter 8: Assessing risk of bias in included studies. In: Higgins JPT, Green S (editors). Cochrane Handbook for Systematic Reviews of Interventions Version 5.1.0 (updated March 2011). The Cochrane Collaboration, 2011. Available from www.cochranehandbook.org.

\section{Hitchings 1983}

Hitchings RA, Grierson I. Clinico pathological correlation in eyes with failed fistulizing surgery. Transactions of the Ophthalmological Societies of the United Kingdom 1983;103(Pt 1):84-8.

\section{Hollows 1966}

Hollows FC, Graham PA. Intra-ocular pressure, glaucoma, and glaucoma suspects in a defined population. British Journal of Ophthalmology 1966;50(10):570-86.

\section{Iliff 1944}

Iliff CE. Surgical control of glaucoma in the negro. American Journal of Ophthalmology 1944;27:731-8. 


\section{Khaw 1991}

Khaw PT, Ward S, Grierson I, Rice NS. Effect of beta radiation on proliferating human Tenon's capsule fibroblasts. British Journal of Ophthalmology 1991;75(10):580-3.

\section{Lavin 1990}

Lavin MJ, Wormald RP, Migdal CS, Hitchings RA. The influence of prior therapy on the success of trabeculectomy. Archives of Ophthalmology 1990;108(11):1543-8.

\section{Leske 1995}

Leske MC, Connell AM, Wu SY, Hyman LG, Schachat AP. Risk factors for open-angle glaucoma. The Barbados Eye Study. Archives of Ophthalmology 1995;113(7):918-24.

\section{Lichter 2001}

Lichter PR, Musch DC, Gillespie BW, Guire KE, Janz NK, Wren PA, et al. Interim clinical outcomes in the Collaborative Initial Glaucoma Treatment Study comparing initial treatment randomized to medications or surgery. Ophthalmology 2001;108(11):1943-53.

\section{Migdal 1986}

Migdal C, Hitchings R. Control of chronic simple glaucoma with primary medical, surgical and laser treatment. Transactions of the Ophthalmological Societies of the United Kingdom 1986;105(Pt 6):653-6.

\section{Miller 1991}

Miller MH, Rice NS. Trabeculectomy combined with beta irradiation for congenital glaucoma. British Journal of Ophthalmology 1991;75(10):584-90.

\section{Quigley 1996}

Quigley HA. Number of people with glaucoma worldwide. British Journal of Ophthalmology 1996;80(5):389-93.

\section{Review Manager 2011 [Computer program]}

The Nordic Cochrane Centre, The Cochrane Collaboration. Review Manager (RevMan). Version 5.1. Copenhagen: The Nordic Cochrane Centre, The Cochrane Collaboration, 2011.

\section{Ritch 1996}

Ritch R, Shields MB, Krupin T. The Glaucomas. St Louis: Mosby, 1996.

\section{Rossetti 1993}

Rossetti L, Orzalesi N, Liberati A. The medical treatment of open angle glaucoma. New England Journal of Medicine 1993;329(10):735-6.

\section{CHARACTERISTICS OF STUDIES}

Characteristics of included studies [ordered by study ID]

\section{Singh 2000}

Singh K, Mehta K, Shaikh NM, Tsai JC, Moster MR, Budenz DL, et al. Trabeculectomy with intraoperative mitomycin $\mathrm{C}$ versus 5- fluorouracil. Prospective randomized clinical trial. Ophthalmology 2000;107(12):2305-9.

\section{Vass 2007}

Vass C, Hirn C, Sycha T, Findl O, Sacu S, Bauer P, Schmetterer L. Medical interventions for primary open angle glaucoma and ocular hypertension. Cochrane Database of Systematic Reviews 2007, Issue 4. [DOI: 10.1002/14651858.CD003167.pub3]

\section{Wilkins 2005}

Wilkins M, Indar A, Wormald R. Intraoperative Mitomycin C for glaucoma surgery. Cochrane Database of Systematic Reviews 2005, Issue 4. [DOI: 10.1002/14651858.CD002897.pub2]

\section{Wolner 1991}

Wolner B, Liebmann JM, Sassani JW, Ritch R, Speaker M, Marmor M. Late bleb-related endophthalmitis after trabeculectomy with adjunctive 5-fluorouracil. Ophthalmology 1991;98(7):1053-60.

\section{Wormald 2001}

Wormald R, Wilkins M, Bunce C. Postoperative 5-Fluorouracil for glaucoma surgery. Cochrane Database of Systematic Reviews 2001, Issue 3. [DOI: 10.1002/14651858.CD001132]

\section{Yaldo 1993}

Yaldo MK, Stamper RL. Long-term effects of mitomycin on filtering blebs. Lack of fibrovascular proliferative response following severe inflammation. Archives of Ophthalmology 1993;111(6):824-6.

\section{Zacharia 1993}

Zacharia PT, Deppermann SR, Schuman JS. Ocular hypotony after trabeculectomy with mitomycin C. American Journal of Ophthalmology 1993;116(3):314-26.

\section{References to other published versions of this review Kirwan 2009}

Kirwan JF, Rennie C, Evans JR. Beta radiation for glaucoma surgery. Cochrane Database of Systematic Reviews 2009, Issue 2. [DOI: 10.1002/14651858.CD003433.pub2]

* Indicates the major publication for the study

Barnes 2000

Methods sealed envelopes, randomised number sequence, 3 lost to FU


Barnes 2000 (Continued)

\begin{tabular}{ll} 
Interventions & trabeculectomy $+/$ - beta radiation \\
\hline Outcomes & IOP $<21=$ success $(+/$ - medication) mean IOP
\end{tabular}

Notes

\section{Risk of bias}

\begin{tabular}{lll}
\hline Bias & Authors' judgement & Support for judgement \\
\hline $\begin{array}{l}\text { Random sequence genera- } \\
\text { tion (selection bias) }\end{array}$ & Unclear risk & $\begin{array}{l}\text { "The patients randomly received or did not receive a dose of beta radiation" } \\
\text { Page 259, last paragraph }\end{array}$ \\
\hline
\end{tabular}

\begin{tabular}{|c|c|c|}
\hline $\begin{array}{l}\text { Allocation concealment } \\
\text { (selection bias) }\end{array}$ & Unclear risk & - \\
\hline $\begin{array}{l}\text { Blinding (performance } \\
\text { bias and detection bias) } \\
\text { All outcomes }\end{array}$ & Low risk & $\begin{array}{l}\text { "There was no record of beta radiation treatment in the patient notes, so at } \\
\text { follow up the examining doctor did not know which arm of the study the pa- } \\
\text { tient belonged to" Bottom of page } 259 \text { top of page } 260 \text {. } \\
\text { We have made the assumption that the patient did not know either although } \\
\text { this was not explicitly stated. }\end{array}$ \\
\hline $\begin{array}{l}\text { Incomplete outcome data } \\
\text { (attrition bias) } \\
\text { All outcomes }\end{array}$ & Unclear risk & $\begin{array}{l}\text { “...follow-up periods ranged between } 3 \text { and } 42 \text { months. Three patients only } \\
\text { had } 3 \text { months follow-up..” Page } 261 \text {, first paragraph. } \\
\text { However, follow-up times for each treatment group were not given. }\end{array}$ \\
\hline $\begin{array}{l}\text { Selective reporting (re- } \\
\text { porting bias) }\end{array}$ & Low risk & $\begin{array}{l}\text { The main outcome reported in this study was intraocular pressure, as would } \\
\text { be expected }\end{array}$ \\
\hline Other bias & Low risk & - \\
\hline
\end{tabular}

\section{Kirwan 2006}

\begin{tabular}{ll}
\hline Methods & $\begin{array}{l}\text { opaque sealed envelopes, envelopes opened immediately before administration of treatment or place- } \\
\text { bo during surgery random number sequence with masking of allocation by outside agency, no exclu- } \\
\text { sions, } 30 \% \text { lost to follow up. }\end{array}$ \\
\hline Participants & Africans $>40$ \\
\hline Interventions & trabeculectomy + beta radiation or dummy application \\
\hline Outcomes & IOP $<21$ without medication \\
\hline Notes & $\begin{array}{l}\text { Risk of bias assessment made on Kirwan et al. BMJ, doi:10.1136/bmj.38971.395301.7C (published 5 Octo- } \\
\text { ber 2006) }\end{array}$ \\
\hline
\end{tabular}

\section{Risk of bias}

\begin{tabular}{lll}
\hline Bias & Authors' judgement & Support for judgement \\
\hline $\begin{array}{l}\text { Random sequence genera- } \\
\text { tion (selection bias) }\end{array}$ & Low risk & "Randomisation was in blocks of 20.. " First sentence, page 2. \\
\hline
\end{tabular}


Kirwan 2006 (Continued)

\begin{tabular}{|c|c|c|}
\hline $\begin{array}{l}\text { Allocation concealment } \\
\text { (selection bias) }\end{array}$ & Low risk & $\begin{array}{l}\text { "... with the assigned groups distributed to each centre in opaque, sealed en- } \\
\text { velopes. Each participant was allocated a trial number on recruitment. The en- } \\
\text { velope with that number was opened during surgery to determine allocation" } \\
\text { Page 2, first paragraph. }\end{array}$ \\
\hline
\end{tabular}

Blinding (performance Low risk

bias and detection bias)

All outcomes
Page 2, first paragraph.

\section{"Separate record sheets were used at follow-up to mask clinicians from the treatment allocation" Page 2, first paragraph.}

\begin{tabular}{|c|c|c|}
\hline $\begin{array}{l}\text { Incomplete outcome data } \\
\text { (attrition bias) } \\
\text { All outcomes }\end{array}$ & Low risk & $\begin{array}{l}\text { "Twenty participants (6\%) dropped out of the study after surgery. Some evi- } \\
\text { dence was found that the probability of not being seen was associated with } \\
\text { sex (women } 10 \% \text { v men } 4 \%: \mathrm{P}=0.03 \text { ), blindness in the fellow eye ( } 9 \% \text { v } 3 \%: \mathrm{P} \\
=0.02) \text {, and centre (Bloemfontein } 2 \% \text {, Edendale } 9 \% \text {, Pretoria } 3 \%: \mathrm{P}=0.09 ; \text { ta- } \\
\text { ble } 1 \text { ). No strong evidence was found for an association with other variables. } \\
\text { A further } 68 \text { patients were lost to follow-up before } 12 \text { months ( } 36 \text { in the radia- } \\
\text { tion arm). Similar mean numbers of follow-up visits were completed in each } \\
\text { of the treatment groups ( } 4.9 \text { radiation group; } 4.5 \text { placebo group; } \mathrm{P}=0.35) \text {. Par- } \\
\text { ticipants who were followed up showed similar distributions for socio-demo- } \\
\text { graphic, ophthalmic, and surgical factors in the treatment arms (table } 1 \text { )." } \\
\text { Page } 2 \text { first paragraph }\end{array}$ \\
\hline
\end{tabular}

From figure 1:

$117 / 156(75 \%)$ in control group followed at 12 months; $115 / 164$ (70\%) of radiation group followed at 12 months.

Selective reporting (re- Low risk All outcomes specified in the protocol were reported in the paper. Jim Kirwan
porting bias)
porting bias)

\begin{tabular}{ll}
\hline Other bias $\quad$ Low risk $\quad-$ \\
\hline
\end{tabular}

\section{Lai 1994}

\begin{tabular}{ll}
\hline Methods & sealed envelopes, randomised number sequence, ? exclusions ? FU \\
\hline Participants & Hong Kong Chinese $>30$ \\
\hline Interventions & trabeculectomy $+/$ - beta radiation \\
\hline Outcomes & IOP $<21=$ success $(+/$ - medication) mean IOP \\
\hline Notes & published in abstract form only \\
\hline
\end{tabular}

\section{Risk of bias}

\begin{tabular}{lll}
\hline Bias & Authors' judgement & Support for judgement \\
\hline $\begin{array}{ll}\text { Random sequence genera- } \\
\text { tion (selection bias) }\end{array}$ & Unclear risk & $\begin{array}{l}\text { "Patients with primary open angle glaucoma whose pressure was over } 21 \\
\text { mmHg on maximum anti-glaucoma medications were assigned randomly to } \\
\text { either Group 1): Trabeculectomy, or Group 2) Trabeculectomy + Intraoperative } \\
\text { beta irradiation." }\end{array}$ \\
& & \\
\hline
\end{tabular}


Lai 1994 (Continued)

Allocation concealment Low risk $\quad$ Adequate allocation concealment reported by investigator
(selection bias)
(selection bias)

Blinding (performance Unclear risk

bias and detection bias)

All outcomes

Incomplete outcome data Unclear risk

(attrition bias)

All outcomes

Selective reporting (re- Unclear risk
porting bias)

Other bias Unclear risk - -

Rehman 2002

\begin{tabular}{ll}
\hline Methods & random number table, no exclusions, no loss to FU \\
\hline Participants & Caucasian $>40$ \\
\hline Interventions & trabeculectomy $+/$ - beta radiation \\
\hline Outcomes & IOP $<21=$ success $(+/$ - medication) mean IOP \\
\hline Notes & recruitment terminated early due to changes in clinical practice \\
\hline
\end{tabular}

\section{Risk of bias}

\begin{tabular}{|c|c|c|}
\hline Bias & Authors' judgement & Support for judgement \\
\hline $\begin{array}{l}\text { Random sequence genera- } \\
\text { tion (selection bias) }\end{array}$ & Low risk & $\begin{array}{l}\text { "A random numbers table was used to assign each eye to either control or beta } \\
\text { irradiation group,?" Page 303, materials and methods, first paragraph, last sen- } \\
\text { tence. }\end{array}$ \\
\hline $\begin{array}{l}\text { Allocation concealment } \\
\text { (selection bias) }\end{array}$ & Low risk & $\begin{array}{l}\text { "...with ophthalmologist and patient masked to the assignment." Page 303, } \\
\text { materials and methods, first paragraph, last sentence. } \\
\text { Given this statement allocation concealment likely. }\end{array}$ \\
\hline $\begin{array}{l}\text { Blinding (performance } \\
\text { bias and detection bias) } \\
\text { All outcomes }\end{array}$ & Low risk & $\begin{array}{l}\text { "Patients in the control group received an identical applicator but without an } \\
\text { active source (an inactive plaque also designed by Amersham). "Page 303, ma- } \\
\text { terials and methods, middle of } 3^{r d} \text { paragraph. } \\
\text { There is not much information on masking but given this statement it would } \\
\text { be unlikely that patients and outcome assessors would know which had re- } \\
\text { ceived beta-radiation. }\end{array}$ \\
\hline $\begin{array}{l}\text { Incomplete outcome data } \\
\text { (attrition bias) } \\
\text { All outcomes }\end{array}$ & Low risk & $\begin{array}{l}\text { No exclusions and no attrition reported. } 61 \text { patients were enrolled into the tri- } \\
\text { al and data on } 61 \text { patients reported at } 12 \text { months for all outcomes ( } 100 \% \text { fol- } \\
\text { low-up). }\end{array}$ \\
\hline
\end{tabular}


Rehman 2002 (Continued)

Selective reporting ( $\mathrm{re}$ Low risk The main outcome reported in this study was intraocular pressure. This is as porting bias) would be expected and in any case there were no statistically significant differences between the groups with respect to this outcome.

Other bias Low risk

Early termination of patient recruitment was reported because patient recruitment was slow. However, this early termination was not determined by the results of the study.

FU: follow up

IOP: intraocular pressure

Characteristics of excluded studies [ordered by study ID]

\begin{tabular}{ll}
\hline Study & Reason for exclusion \\
\hline Tesha 2002 & Further report of data in Rehman's study in abstract form \\
\hline
\end{tabular}

DATA AND ANALYSES

\section{Comparison 1. Surgical failure}

\begin{tabular}{lllll}
\hline Outcome or subgroup title & $\begin{array}{l}\text { No. of } \\
\text { studies }\end{array}$ & $\begin{array}{l}\text { No. of } \\
\text { partici- } \\
\text { pants }\end{array}$ & Statistical method & Effect size \\
\hline $\begin{array}{l}1 \mathrm{IOP}>21 \mathrm{mmHg} 12 \text { months or more } \\
\text { after surgery }\end{array}$ & 4 & RR (Fixed, 95\% Cl) & $0.23[0.14,0.40]$ \\
\hline 1.1 Black African people & 1 & RR (Fixed, 95\% Cl) & $0.21[0.11,0.40]$ \\
\hline 1.2 Caucasian people & 2 & RR (Fixed, 95\% Cl) & $0.15[0.02,1.28]$ \\
\hline 1.3 Chinese people & 1 & RR (Fixed, 95\% Cl) & $0.34[0.12,0.96]$ \\
\hline
\end{tabular}

Analysis 1.1. Comparison 1 Surgical failure, Outcome 1 IOP > 21 mmHg 12 months or more after surgery.

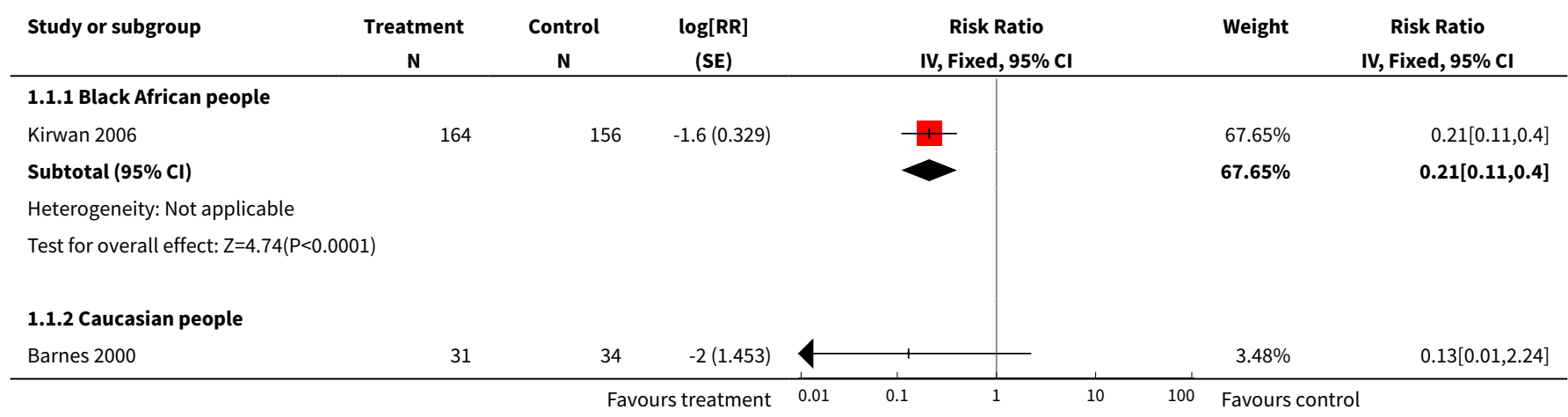




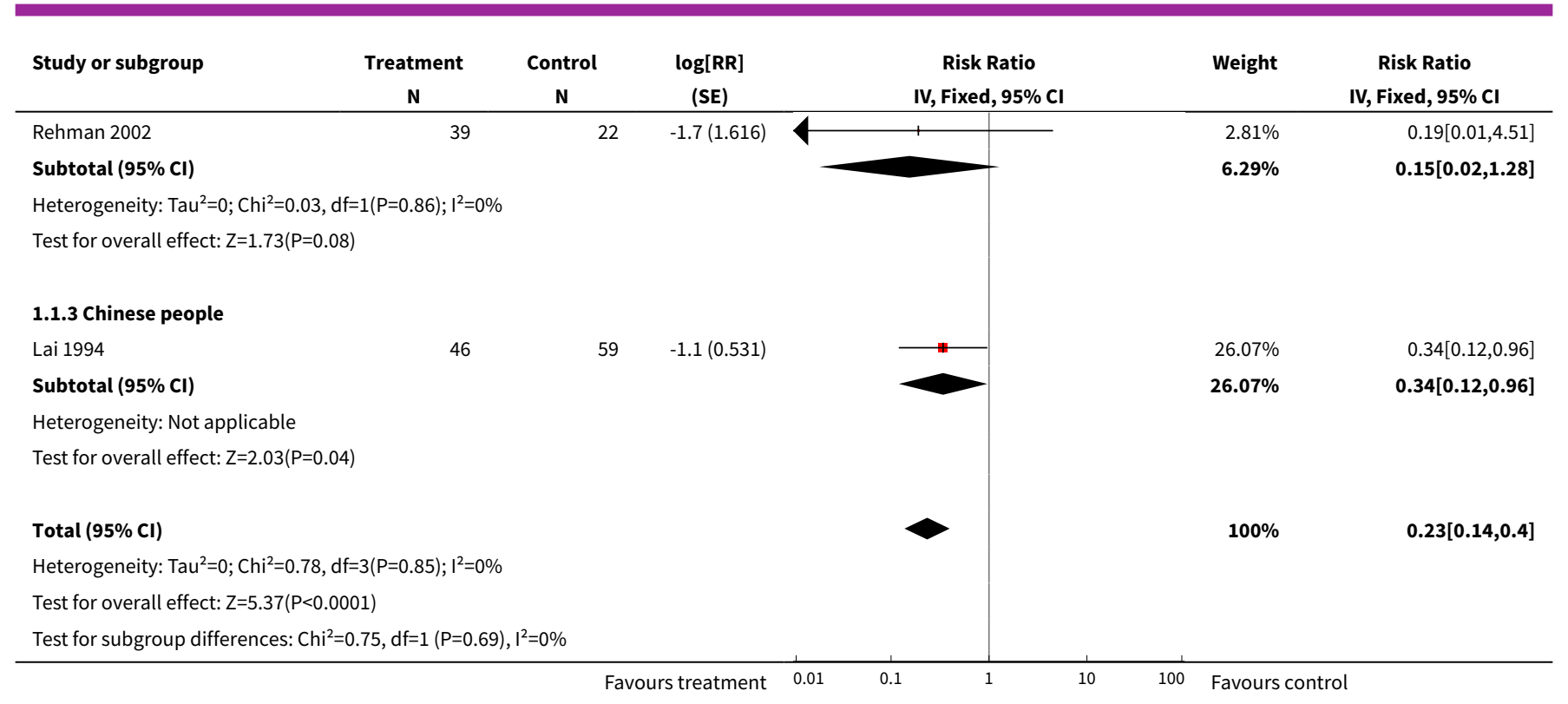

\section{Comparison 2. Intraocular pressure (IOP)}

\begin{tabular}{lllll}
\hline Outcome or subgroup title & $\begin{array}{l}\text { No. of } \\
\text { studies }\end{array}$ & $\begin{array}{l}\text { No. of par- } \\
\text { ticipants }\end{array}$ & Statistical method & Effect size \\
\hline $\begin{array}{l}1 \text { Mean IOP 12 months or more after } \\
\text { surgery }\end{array}$ & 2 & 123 & Mean Difference (IV, Fixed, 95\% Cl) & $-0.97[-2.56,0.62]$ \\
\hline
\end{tabular}

Analysis 2.1. Comparison 2 Intraocular pressure (IOP), Outcome 1 Mean IOP 12 months or more after surgery.

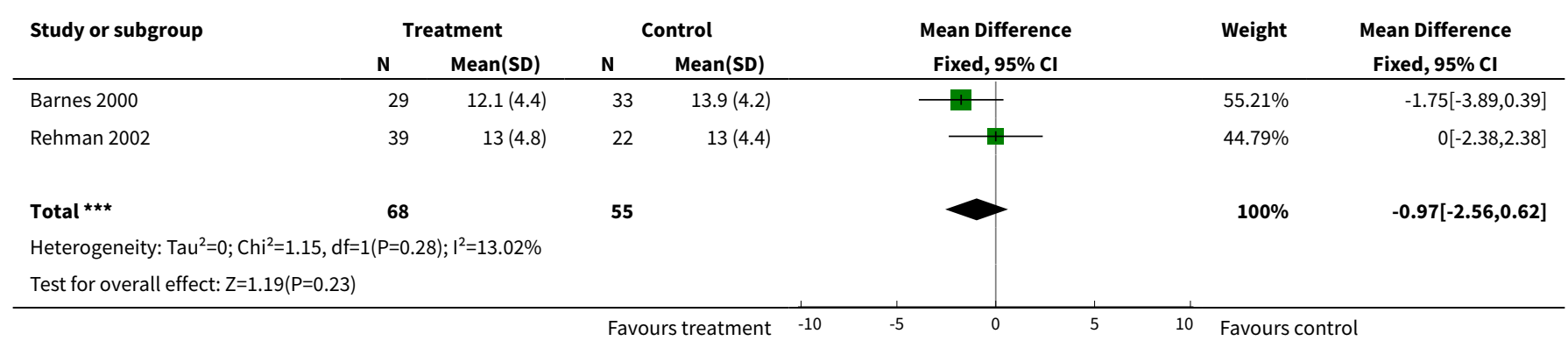

\section{Comparison 3. Adverse effects}

\begin{tabular}{lllll}
\hline $\begin{array}{l}\text { Outcome or subgroup } \\
\text { title }\end{array}$ & $\begin{array}{l}\text { No. of } \\
\text { studies }\end{array}$ & $\begin{array}{l}\text { No. of } \\
\text { partici- } \\
\text { pants }\end{array}$ & Statistical method & Effect size \\
\hline 1 Cataract & 2 & 362 & Risk Ratio (M-H, Fixed, 95\% Cl) & $2.89[1.39,6.00]$ \\
\hline 2 Hypotony & 3 & 423 & Risk Ratio (M-H, Fixed, 95\% Cl) & $1.79[0.62,5.14]$ \\
\hline
\end{tabular}




\begin{tabular}{lllll}
\hline $\begin{array}{l}\text { Outcome or subgroup } \\
\text { title }\end{array}$ & $\begin{array}{l}\text { No. of } \\
\text { studies }\end{array}$ & $\begin{array}{l}\text { No. of } \\
\text { partici- } \\
\text { pants }\end{array}$ & Statistical method & Effect size \\
\hline 3 Bleb leak & 2 & 123 & Odds Ratio (M-H, Fixed, 95\% Cl) & $0.53[0.12,2.38]$ \\
\hline
\end{tabular}

Analysis 3.1. Comparison 3 Adverse effects, Outcome 1 Cataract.

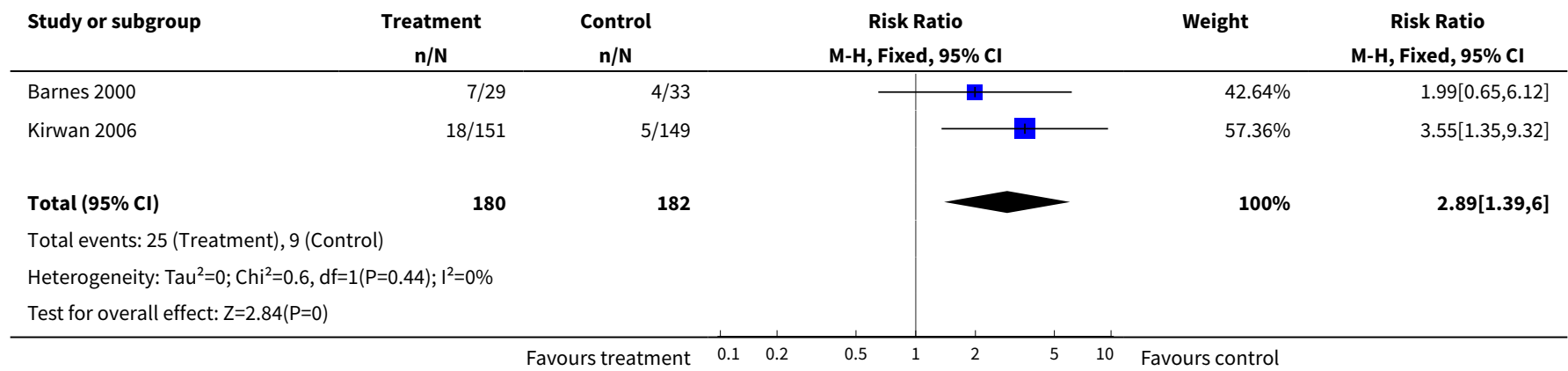

\section{Analysis 3.2. Comparison 3 Adverse effects, Outcome 2 Hypotony.}

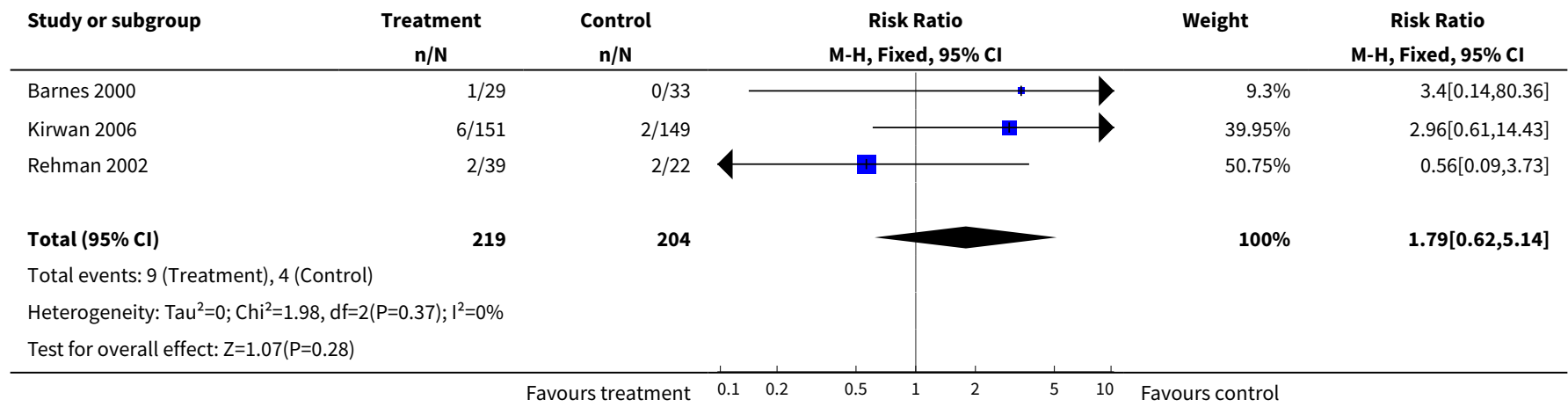

\section{Analysis 3.3. Comparison 3 Adverse effects, Outcome 3 Bleb leak.}

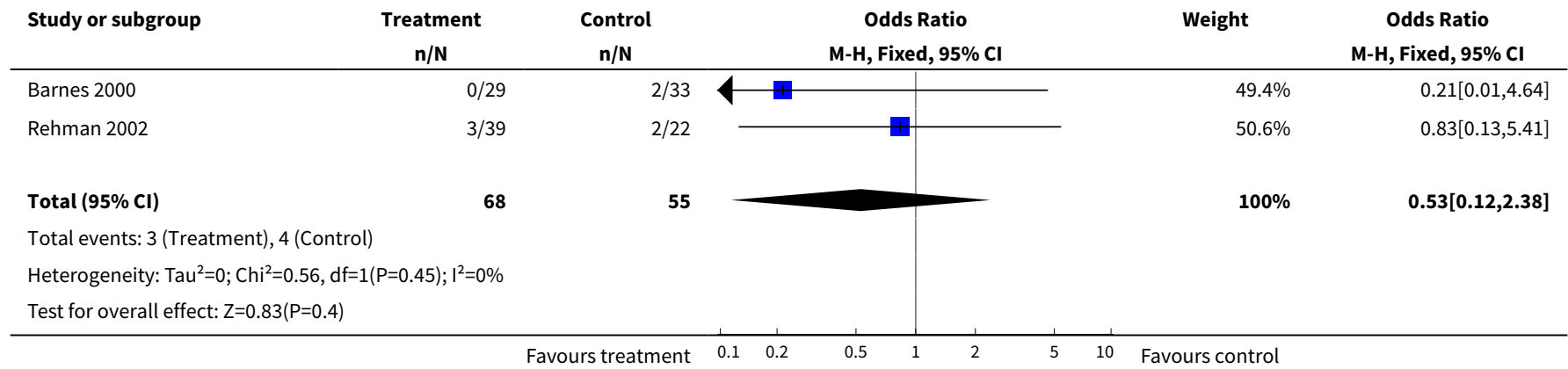




\section{ADDITIONAL TABLES}

Table 1. Summary of trial characteristics

\begin{tabular}{llllll}
\hline Study & Ethnic group & Dose & $\begin{array}{l}\text { N treat- } \\
\text { ment } \\
\text { group }\end{array}$ & $\begin{array}{l}\text { N control } \\
\text { group }\end{array}$ & $\begin{array}{l}\text { Surgical failure at 12 months } \\
\text { in control group }\end{array}$ \\
\hline Barnes 2000 & Caucasian & 750 cGy & 31 & 34 & $12 \%$ \\
\hline Kirwan 2006 & Black African & $1000 \mathrm{cGy}$ & 164 & 156 & $30 \%$ \\
\hline Lai 1994 & Chinese & $1000 \mathrm{cGy}$ & 46 & 59 & $26 \%$ \\
\hline Rehman 2002 & Caucasian & $750 \mathrm{cGy}$ & 39 & 22 & $14 \%$ \\
\hline
\end{tabular}

\section{A P PEN DICES}

\section{Appendix 1. CENTRAL search strategy}

\#1 MeSH descriptor Glaucoma

\#2 MeSH descriptor Filtering Surgery

\#3 (glaucoma* or filter* or filtrat ${ }^{\star}$ ) near (surg*)

\#4 MeSH descriptor Trabeculectomy

\#5 trabeculectom*

\#6 (\#1 OR \#2 OR \#3 OR \#4 OR \#5)

$\# 7 \mathrm{MeSH}$ descriptor Beta Rays

\#8 MeSH descriptor Radiation

\#9 MeSH descriptor Strontium

\#10 MeSH descriptor Brachytherapy

\#11 radiat* or irradiat ${ }^{\star}$

\#12 strontium or SR 90

$\# 13$ beta-rad* or beta irrad ${ }^{*}$

\#14 (\#7 OR \#8 OR \#9 OR \#10 OR \#11 OR \#12 OR \#13)

\#15 (\#6 AND \#14)

\section{Appendix 2. MEDLINE (OvidSP) search strategy}

1. randomized controlled trial.pt.

2. (randomized or randomised).ab,ti.

3. placebo.ab,ti.

4. dt.fs.

5. randomly.ab,ti.

6. trial.ab,ti.

7. groups.ab,ti.

8. or/1-7

9. exp animals/

10. exp humans/

11.9 not (9 and 10)

12. 8 not 11

13. exp glaucoma/

14. exp filtering surgery/

15. ((glaucoma $\$$ or filter\$ or filtrat\$) adj3 surg\$).tw.

16. trabeculectom\$.tw.

17. or/13-16

18. beta particles/

19. exp radiation/

20. strontium/ 
21. exp brachytherapy/

22. (radiat\$ or irradiat\$).tw.

23. (strontium\$ or SR 90).tw.

24. (beta-radiat\$ or beta-irradiat\$).tw.

25. or/18-24

26. 17 and 25

27. 12 and 26

The search filter for trials at the beginning of the MEDLINE strategy is from the published paper by Glanville et al (Glanville 2006).

\section{Appendix 3. EMBASE (OvidSP) search strategy}

1. exp randomized controlled trial/

2. exp randomization/

3. exp double blind procedure/

4. exp single blind procedure/

5. random\$.tw.

6. or/1-5

7. (animal or animal experiment).sh.

8. human.sh.

9.7 and 8

10.7 not 9

11.6 not 10

12. exp clinical trial/

13. (clin\$ adj3 trial\$).tw.

14. ((singl\$ or doubl\$ or trebl\$ or tripl\$) adj3 (blind\$ or mask\$)).tw.

15. exp placebo/

16. placebo\$.tw.

17. random\$.tw.

18. exp experimental design/

19. exp crossover procedure/

20. exp control group/

21. exp latin square design/

22. or $/ 12-21$

23. 22 not 10

24. 23 not 11

25. exp comparative study/

26. exp evaluation/

27. exp prospective study/

28. (control\$ or prospectiv\$ or volunteer\$).tw.

29. or $/ 25-28$

30.29 not 10

31.30 not (11 or 23 )

32. 11 or 24 or 31

33. exp glaucoma/

34. exp glaucoma surgery/

35. ((glaucoma\$ or filter\$ or filtrat\$) adj3 surg\$).tw.

36. trabeculectom\$.tw.

37. or/33-36

38. beta radiation/

39. exp irradiation/

40. strontium 90/

41. exp brachytherapy/

42. (radiat\$ or irradiat\$).tw.

43. (strontium\$ or SR 90).tw.

44. (beta-radiat\$ or beta-irradiat\$).tw.

45. or/38-44

46. 37 and 45

47.32 and 46

Appendix 4. metaRegister of Controlled Trials search strategy

beta radiation and glaucoma 


\section{Appendix 5. ClinicalTrials.gov search strategy}

Beta Radiation AND Glaucoma

\section{Appendix 6. ICTRP search strategy}

beta radiation AND glaucoma

\section{WHAT'S NEW}

\begin{tabular}{lll}
\hline Date & Event & Description \\
\hline 9 May 2012 & $\begin{array}{l}\text { New citation required but conclusions } \\
\text { have not changed }\end{array}$ & $\begin{array}{l}\text { Issue 6, 2012: New no trials were identified that met the inclusion } \\
\text { criteria. }\end{array}$ \\
\hline 9 May 2012 & New search has been performed & Issue 6, 2012: Electronic searches were updated. \\
\hline
\end{tabular}

\section{H I S T O R Y}

Protocol first published: Issue 1, 2002

Review first published: Issue 2, 2009

\begin{tabular}{lll}
\hline Date & Event & Description \\
\hline 17 March 2008 & Amended & Converted to new review format. \\
\hline
\end{tabular}

\section{CONTRIBUTIONS OF AUTHORS}

JK wrote the protocol and assessed studies for inclusion, assessed studies for risk of bias, analysed the results and wrote the text of the review. CR assessed studies for inclusion and risk of bias and helped draft the review. JE assessed studies for risk of bias, extracted and entered data, did the summary of findings table and edited the text of the review.

\section{DECLARATIONSOF INTEREST}

One of the review authors (JFK) has conducted an RCT into the effects of beta radiation on augmenting the success of glaucoma surgery in Africans in South Africa.

\section{SOURCES OF SUPPORT}

\section{Internal sources}

- Institute of Ophthalmology, UK.

- NIHR/Department of Health, UK.

JE was funded by NIHR during the updating of this review (Issue 6, 2012)

\section{External sources}

- No sources of support supplied

\section{DIFFERENCES BETWEEN PROTOCOLAND REVIEW}

Analysis by ethnic group conducted in the review but not specified in the protocol. 


\section{N D EX TERMS}

\section{Medical Subject Headings (MeSH)}

Beta Particles [adverse effects] [ ${ }^{\star}$ therapeutic use]; Cataract [etiology]; Combined Modality Therapy [methods]; Glaucoma [ ${ }^{\star}$ surgery]; Randomized Controlled Trials as Topic; Trabeculectomy [ ${ }^{\star}$ methods]; Treatment Outcome; Wound Healing [ ${ }^{\star}$ radiation effects]

\section{MeSH check words}

Humans 